\title{
Kulturne i kreativne industrije u post- pandemijskom svijetu: utjecaj pandemije na poslovanje radijskih nakladnika u Hrvatskoj
}

Prethodno priopćenje, DOI 10.22522/cmr20210165, primljeno 9. svibnja 2021.

UDK: $\quad 008-026.15: 338.3$

$655.41: 656.254 .1$

$616-036.21$

\section{Silvija Londero Šimleša}

Sveučilište VERN, Edward Bernays University College, Media servis global, Zagreb, Hrvatska.

E-adresa: silvija.londero.simlesa@mediaservis.hr

\section{Sažetak}

Pandemija virusa COVID-19 u potpunosti je promijenila sliku svijeta. Jedna od grana koje su najpogođenije posljedicama pandemije su kulturne i kreativne industrije. Ni medijsko tržište, kao važan dio sektora kulturnih i kreativnih industrija, nije bilo pošteđeno ovog udara. U radu se istražuje kako je pandemija virusa COVID-19 utjecala na upravljanje i poslovanje elektroničkih medija u Hrvatskoj na primjeru radijskih nakladnika te kako su se oni prilagodili promjenama u financijskom, tehnološkom i kadrovskom smislu, ali i drugim segmentima poslovanja. Dobiveni rezultati uspoređeni su s podacima radijskih tržišta Europske unije i zemalja u okruženju. Drugačije okolnosti na tržištu stvorile su nove modele poslovanja od kojih su neki zadržani kao praksa. Rad istražuje i mjere potpora i relaksacija zakonskih obveza državnih institucija i agencija kojima su one reagirale na promjene u poslovanju radijskih nakladnika u Hrvatskoj.

Ključne riječi: pandemija, kulturne i kreativne industrije, radijski nakladnici 


\section{Uvod}

U drugoj godini pandemije virusa COVID-19 slika svijeta u potpunosti je drugačija. Nema grane gospodarstva koja nije pogođena krizom uzrokovanom pandemijom. Kulturne i kreativne industrije, jedna od značajnijih grana sektora gospodarstva koja prednjači u području investicija i zaposlenosti te bilježi brži rast od prosjeka rasta drugih industrija u Europskoj uniji, pandemijom su pogođene čak više od turističkog sektora. Ni medijsko tržište, kao važan dio sektora kulturnih i kreativnih industrija, nije bilo pošteđeno ovog udara. Poslovanje i upravljanje medijima promijenilo se iz temelja, a u godini krize ključno je bilo ne zaustaviti poslovne procese, osigurati likvidnost i zadržati radne pozicije.

Radijski medij jedan je od grana kulturnih i kreativnih industrija. Ovaj rad istražuje kako je pandemija virusa COVID-19 utjecala na upravljanje i poslovanje elektroničkih medija u Hrvatskoj na primjeru radijskih nakladnika, kako je promijenila poslovne procese te kako su se radijski nakladnici prilagodili promjenama u financijskom, tehnološkom i kadrovskom smislu, ali i drugim segmentima poslovanja. Dobiveni rezultati uspoređeni su s podacima radijskih tržišta Europske unije i zemalja u okruženju. Rad analizira i koje su nove modele poslovanja stvorile drugačije okolnosti na tržištu, koji su od njih zadržani kao praksa te hoće li se zadržati u poslovnom okruženju radijskih nakladnika u post-pandemijskom svijetu. Rad istražuje i kojim su mjerama potpora i relaksacija zakonskih obveza državne institucije i agencije reagirale na promjene u poslovanju ovog važnog segmenta gospodarstva.

\subsection{Utjecaj pandemije virusa COVID-19 na kulturne i kreativne industrije}

Pojam kulturnih industrija prisutan je $\mathrm{u}$ analizama kulturnih politika dugi niz godina, a naknadno mu se pridružuje i drugačija verzija iste fraze - kreativne industrije, objašnjava Hesmondhalgh (2008). Prema Galloway i Dunlopu (2007), termini „kulturne industrije“ i „kreativne industrije“ često se koriste naizmjenično, zbog nejasne razlike između ta dva pojma.

Kulturne i kreativne industrije jedna su od najvažnijih i najprofitabilnijih grana gospodarskog sektora, posebice u dijelu investicija i zapošljavanja. Imaju brz gospodarski rast, brži od većine drugih industrija u Europskoj uniji. U godini prije pandemije, kulturne i kreativne industrije predstavljale su 4,4\% BDP-a Europske unije, što je godišnji promet 
od 643 milijarde eura te ukupnom dodanom vrijednošću od 253 milijarde eura (Zamp.hr, 2021). U 2019. godini imale su brži rast (2,6\%) od prosjeka drugih gospodarskih grana u ukupnom gospodarskom sektoru Europske unije (2\%), dok je njihova trgovinska bilanca bila u plusu 8,6 milijarda eura. Vodeću ulogu prije pandemije virusa COVID-19, kulturne i kreativne industrije imale su u investicijama i zapošljavanju. U 2019. godini zapošljavale su više od 7,6 milijuna ljudi.

Prema „Mapiranju kulturnih i kreativnih industrija u Republici Hrvatskoj“, koje je u 2014. i 2015. godini provela Hrvatska udruga poslodavaca za Hrvatski klaster konkurentnosti kreativnih i kulturnih industrija, sektor kreativnih i kulturnih industrija u Hrvatskoj čini 12 podsektora s ukupno 45 djelatnosti (Hup.hr, n.p.): muzeji, knjižnice i baština; umjetnost; glazba i izvedbene umjetnosti; film; fotografija; elektronički mediji; računalni programi, igre i novi mediji; zanati (umjetnički i tradicijski obrti); arhitektura; izdavaštvo; dizajn te oglašavanje i tržišno komuniciranje. Prema istom istraživanju HUP-a, kulturne i kreativne industrije u Hrvatskoj predvodnik su jačanja „kulture stvaranja“ $i$ „kreativne ekonomije“ $u$ hrvatskom gospodarstvu te su nositelj inovacija uz iznadprosječan broj samozaposlenih. U Hrvatskoj su, prije pandemije uzrokovane virusom COVID-19, ostvarivale više od 15 milijardi kuna prihoda godišnje i zapošljavale više od 42 tisuće ljudi (Hup.hr, 2015). Stoga su Hrvatski klaster konkurentnosti kreativnih i kulturnih industrija te Hrvatska udruga poslodavaca zajedno oformili platformu „Kreativna Hrvatska“ kako bi značajnije iskoristili gospodarski potencijal ovog industrijskog sektora, čije su glavne prepreke razvoja ograničavajući propisi i neprepoznavanje ovih industrija kao važnih gospodarskih čimbenika.

Kao ni većina drugih gospodarskih grana, kulturne i kreativne industrije nisu bile pošteđene udara koronakrize na ukupni segment gospodarstva. Stoga su glavni izazovi u pandemiji bili kako nastaviti poslovne procese, osigurati likvidnost i zadržati radna mjesta. Studija Ernst \& Young-a pod nazivom „Obnova Europe: Kulturno i kreativno gospodarstvo prije i nakon COVIDa-19“" (Rebuilding-europe.eu, 2021), koja je objavljena u siječnju 2021. godine, a provedena za Europsko udruženje autorskih društava, govori kako su kulturne i kreativne industrije kao cjelina u 2020. godini doživjele financijske gubitke veće od 31\%, što iznosi više od 216 milijarda eura, dok gubici u pojedinim sektorima kulturnih i kreativnih industrija, poput sektora glazbe i umjetnosti, dosežu i do $90 \%$. Najugroženije posljedicama pandemije bile su zemlje središnje i istočne Europe, poput Litve, Bugarske i Estonije. 
Kao što je vidljivo na grafikonu 1, najpogođeniji sektori kulturnih i kreativnih industrija pandemijom virusa COVID-19 su glazba (-76\%) i izvedbene umjetnosti (-90\%). Gubici u radijskoj industriji na razini Europske unije dosežu 20\%, dok je jedina grana koja je stekla profit industrija videoigara $(+9 \%)$.

Grafikon 1. Promjene u prometu kulturnih i kreativnih industrija u 2020. godini (izvor: Eurostat; GESAC; profesionalne organizacije; Oxford Economics; EY modeliranje i analiza, 2020)

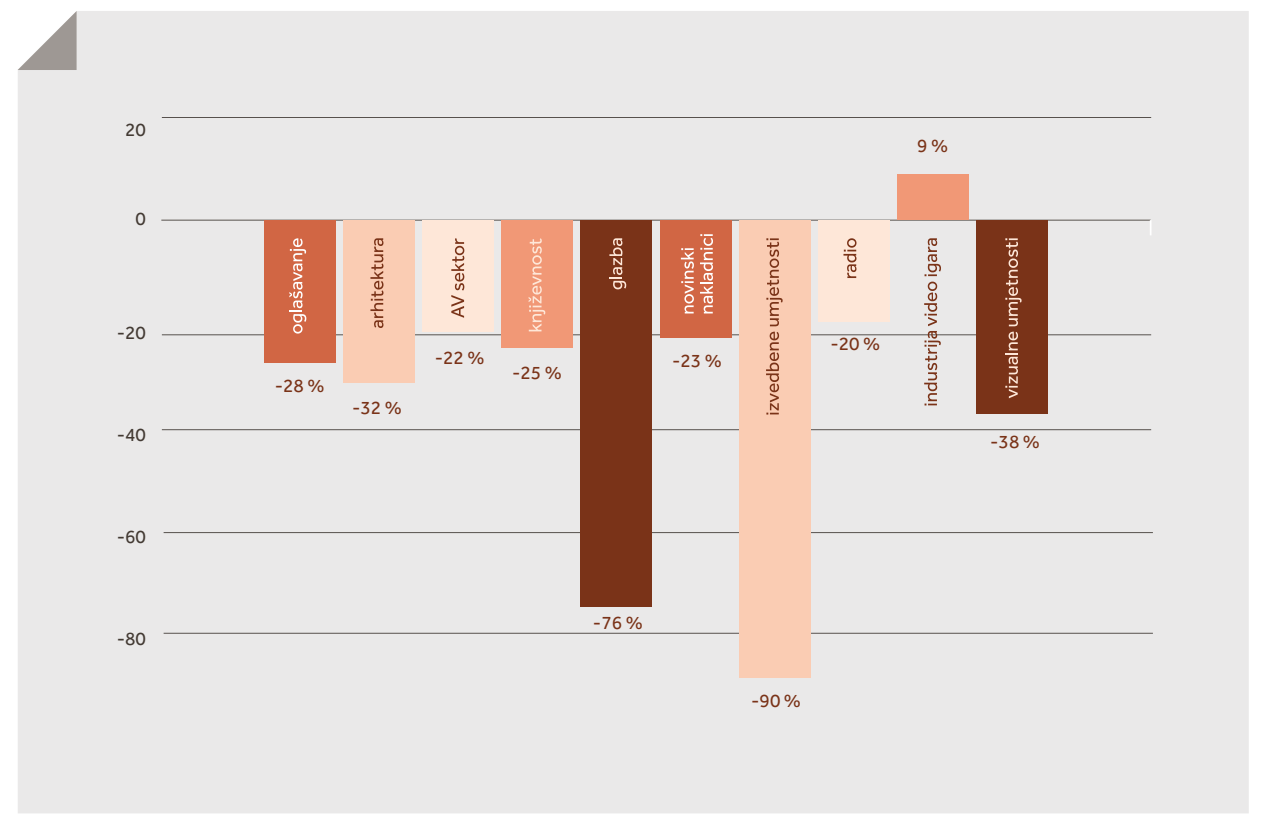

Budući da je kulturni i kreativni sektor jedan od najbrže rastućih i najprofitabilnijih grana europskog gospodarstva, studija zaključuje kako može jednakom mjerom doprinijeti i njegovom oporavku u post-pandemijskom razdoblju. Ista studija preporučuje trostruki pristup oporavku kroz „financije, osnaživanje i polugu“. Riječ je o oslanjanju na „masovno javno financiranje i promicanje privatnih ulaganja, čvrst pravni okvir za stvaranje uvjeta potrebnih za revitalizaciju kreativne ekonomije i osiguravanje njezina dugoročnog rasta te iskorištavanje snage kulturnih i kreativnih industrija i individualnih kreativnih talenata za pokretanje društvenog napretka“ (Rebuilding-europe.eu, 2021). 


\subsection{Utjecaj pandemije virusa COVID-19 na radijsko tržište}

Osim što je utjecala na poslovanje radijskih nakladnika, pandemija uzrokovana virusom COVID-19 promijenila je i odnos radijskog medija i publike. Radio je prvi medij kojemu se publika okreće u kriznim situacijama, zbog brzine informiranja i jednostavne dostupnosti. Prema istraživanju Europske radiodifuzijske unije „Trust in media 2020“, koje je provedeno u lipnju 2020. godine (Horizont.net, 2021), radio je medij kojemu publika u Europi najviše vjeruje. Najviša razina povjerenja u radijski medij bilježi se u čak 79\% europskih zemalja. Zemlje s najnižom stopom povjerenja u radio su Španjolska i zemlje jugoistočne Europe, dok je povjerenje u radio najviše u sjevernoj i središnjoj Europi. Također, istraživanje pokazuje pozitivan trend povjerenja publike u radijski medij s petogodišnjim indeksom porasta povjerenja. Istraživanje donosi i zanimljivu poveznicu između povjerenja u radijske i televizijske medije te slobode medija, ističući kako su ova dva pokazatelja međuovisna.

Modernizacija tehnologije redefinirala je odnos između publike i medija. Prema Livingstoneu (1999), među najznačajnijim promjenama u tom odnosu jest prelazak iz jednosmjerne u dvosmjernu komunikaciju. Zgrabljić Rotar (2011) naglašava kako interaktivna publika pretpostavlja aktivno korištenje medija i kreativnog sudjelovanja u proizvodnji programa. Nastavlja kako su se razvojem tržišta i tehnologije promijenila i očekivanja publike koja od radijskog medija traži brzinu izvještavanja, bogatstvo informacija, multimedijske formate i interaktivnost. Upravo zbog te svoje specifičnosti, naglašava Tomić (2017), radijski medij pruža brojne mogućnosti za prenošenje poruke: informativni program, najave događaja, aktualnosti, talk-show emisije, uredničke komentare, zabavni program i lokalne događaje. No, od svih tih formata korisnici medija više će vjerovati temama postavljenima u informativnom programu jer su „informativni mediji najistaknutiji instrumenti za širenje poruka u društvu“, ističe Larsson (2009, str. 133). Za Verčič i Vučković (2010, str. 45) „medijska zastupljenost oblikuje percepciju javnosti o relativnoj važnosti određenih pitanja u odnosu na neka druga“, a javnosti se nudi sadržaj koji postaje tema, te se određuje relativan značaj pojedinih pitanja.

U doba pandemije promijenila se i slušanost radija. Prema podacima Udruženja europskih radija (Association od European Radios - AER), koje okuplja više od 5000 radijskih postaja u Europskoj uniji i Švicarskoj, vidljivo je kako se na razini Europe slušanost radija održava stabilnom, uz porast slušanosti na digitalnim platformama. Na grafikonu 2, koji uspoređuje 
slušanost radijskih nakladnika u Hrvatskoj prema kvartalima 2019. i 2020. godine, vidljivo je kako je slušanost radija na FM formatu pala tijekom lockdowna te se izjednačila u trećem kvartalu.

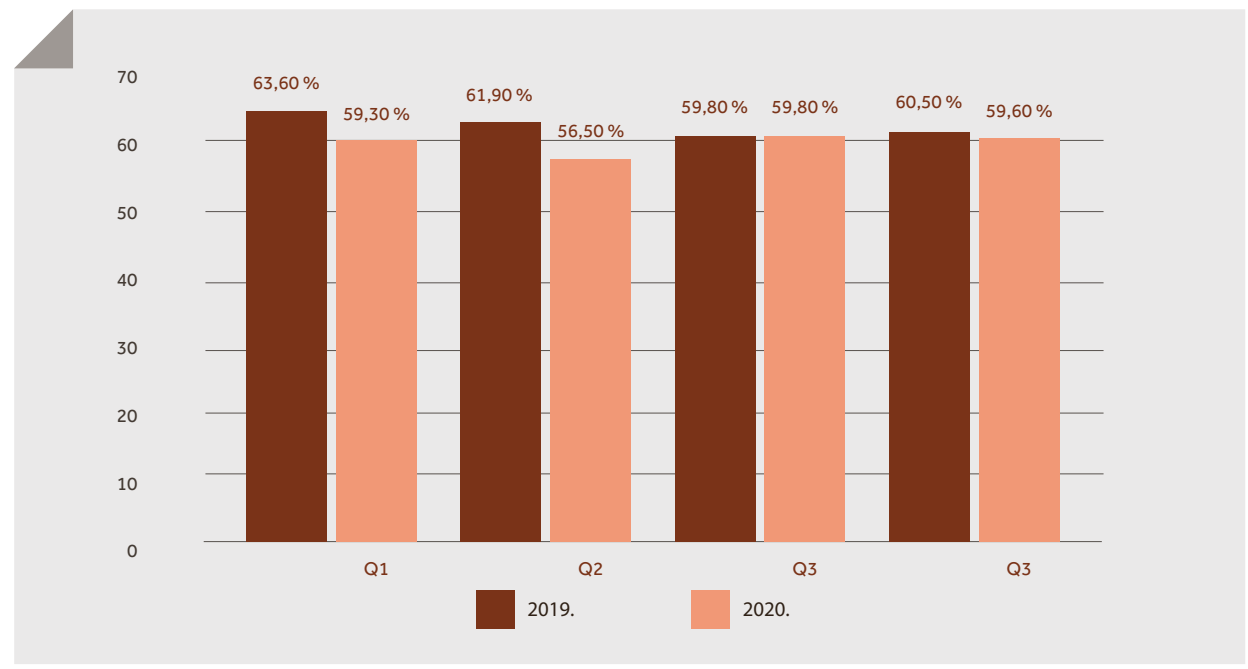

Grafikon 2. Slušanost radija po kvartalima 2019. i 2020. godine (izvor: rad autorice prema podacima amm All market media/Ipsos, uzorak: 5930 - 7734)

Financijski podaci radijskih nakladnika za zemlje članice AER-a govore kako su u 2020. godini gubici u prihodima bili između 5\% i 32\%, s najvećim padom u Španjolskoj, a najmanjim u Švicarskoj. Među zemljama koje broje najmanje gubitke u prihodima još su Ujedinjeno Kraljevstvo, Norveška, Danska i Francuska (tablica 1). 
Tablica 1. Promjene u prihodima na radijskom tržištu u zemljama članicama AER-a u 2020. godini (izvor: rad autorice prema podacima AER-a, 2020)

\begin{tabular}{|l|l|}
\hline ZEMLJA & PRIHODI U 2020. \\
\hline Španjolska & $-32 \%$ \\
\hline Francuska & $-16,2 \%$ \\
\hline Finska & $-20,3 \%$ \\
\hline Italija & $-25 \% /-26 \%$ \\
\hline Austrija & $-15 \% /-20 \%$ \\
\hline Hrvatska & $-25 \%$ \\
\hline Norveška & $-13 \%$ \\
\hline Irska & $-12 \%$ \\
\hline Grčka & $-25 \%$ \\
\hline Danska & $-15 \% /-20 \%$ \\
\hline Ujedinjeno Kraljevstvo & $-14,3 \%$ \\
\hline Švicarska & $-5 \% /-10 \%$ \\
\hline
\end{tabular}

Nadalje, tablica 2 nam prikazuje podatke hrvatskih radijskih nakladnika, članova Koordinacije komercijalnih radijskih postaja pri Hrvatskoj udruzi poslodavaca. Vidljivo je kako, uz gubitke u prihodima od 25\%, u hrvatskom radijskom sektoru nije bilo značajnijih gubitaka radnih mjesta, dok su se prihodi smanjivali većinom samo u menadžmentu. Radijski nakladnici također su smanjili investicije što se većinom odnosi na organizaciju evenata, odnosno produžetak osnovne djelatnosti radijskog medija.

Tablica 2. Promjene na radijskom tržištu u Hrvatskoj tijekom pandemije (izvor: rad autorice prema podacima Hrvatske udruge poslodavaca - Koordinacije komercijalnih radijskih postaja)

\begin{tabular}{|l|l|}
\hline PRIHODI U 2020. & \multicolumn{1}{|c|}{$-\mathbf{2 5 \%}$} \\
\hline Smanjenje zaposlenosti & $-17 \%$ (procjena pada u prihodima za 2021.) \\
\hline Smanjenje u plaćama & 0 \\
\hline Smanjenje investicija & $20 \%$ (menadžment) \\
\hline Investicije u nove poslovne modele & da, digitalne \\
\hline
\end{tabular}




\subsection{Strukturirani intervju s direktorima radijskih nakladnika u Hrvatskoj}

Kako bismo ispitali promjene u poslovanju na radijskom tržištu u Hrvatskoj pristupili smo provedbi strukturiranih dubinskih intervjua s odgovornim osobama radijskih nakladnika u Hrvatskoj. Strukturirani intervjui provedeni su u veljači i ožujku 2021. godine elektroničkom poštom, a ispitani su direktori radijskih nakladnika koji predstavljaju sva koncesijska područja - jedne nacionalne komercijalne radijske postaje, jedne regionalne komercijalne radijske postaje, jedne županijske komercijalne radijske postaje, jedne lokalne komercijalne radijske postaje i nacionalne prodajne agencije specijalizirane za prodaju oglasnog prostora na radijskom tržištu u Hrvatskoj. Iako je istraživanje provedeno s odgovornim osobama radijskih postaja koje predstavljaju sva koncesijska područja u Hrvatskoj, uzorak je prigodan te je riječ o mikro istraživanju koje služi kao podloga za daljnja istraživanja. Ovakvi se rezultati istraživanja odnose isključivo na ispitanu mikro skupinu te se zbog ograničenja koje predstavlja ovako selektirani uzorak ne mogu donositi zaključci za cjelovito tržište. Za širu i potpunu sliku utjecaja pandemije koronavirusa na poslovanje radijskih nakladnika u Hrvatskoj i dublje razumijevanje teme preporučuje se dubinski ispitati cjelovito tržište, odnosno odgovorne osobe svih radijskih nakladnika u Hrvatskoj, njih 151 (Pmu.e-mediji. hr, 2021). Priloženo istraživanje može poslužiti kao podloga za daljnja istraživanja.

Ispitivanju su pristupili: direktor radijske postaje Narodni Katijan Knok, direktor radijske postaje Radio Dalmacija Hrvoje Turić, direktor radijske postaje Antena Zagreb Hrvoje Barišić, direktor radijske postaje Enter Zagreb Dario Antunović te direktor agencije AMM - All Market Media Hrvoje Vukušić. Ispitanicima je postavljeno sljedećih pet pitanja:

1. Kako je pandemija virusa COVID-19 utjecala na radijsko tržište u Hrvatskoj? Što se promijenilo u upravljanju medijima, konkretno u upravljanju radijskim nakladnicima?

2. Na koji je način pandemija virusa COVID-19 utjecala na poslovanje Vašeg medija? Kako ste se prilagodili promjenama u npr. financijskom, tehnološkom i kadrovskom smislu, ali i drugim segmentima poslovanja?

3. Jeste li u promijenjenim okolnostima na tržištu stvorili nove modele poslovanja kako biste unaprijedili poslovne procese i, ako jeste, koji su to novi poslovni modeli? 
4. Kako procjenjujete da će se ove promjene odraziti na poslovanje radijskih nakladnika u post-pandemijskom svijetu? Koje od promjena ste zadržali u poslovanju i koje ćete zadržati nakon pandemije virusa COVID-19?

5. Jesu li Vam neke od mjera potpora državnih institucija i agencija bile od pomoći i, ako jesu, koje su to?

Iz odgovora ispitanika vidljivo je kako je glavna briga poslodavaca na radijskom tržištu bila kako sačuvati radna mjesta, ali i investirati u dodatnu opremu kako bi zaštitili zaposlenike kao i u edukaciju zaposlenika. Publika se djelomično prebacila na digitalne platforme, a radijski nakladnici emitirali su program iz dislociranih studija: „Svaka industrija nosi svoje zakonitosti u svakodnevnom radu, međutim svima je zajedničko da ukoliko želite ostvariti rezultate u borbi protiv virusa COVID-19 morate postati odgovorni, $i$ to je bila prva i glavna pretpostavka uspjeha na kojoj smo inzistirali od prvog dana prema našim zaposlenicima.“, istaknuo je direktor radijske postaje Narodni Katijan Knok.

Gubitci u oglašavanju bili su najistaknutiji u sektoru zabave, evenata i uslužnih djelatnosti, zapravo kroz sve segmente poslovnih djelatnosti koje su bile obustavljene tijekom razdoblja lockdowna. Tržište se rekonstruiralo, klijenti više ne zakupljuju dugoročne kampanje niti planiraju kampanje na duge staze. Aktivnosti u oglašavanju planiraju se najviše dva tjedna unaprijed zbog nesigurnog tržišta, poručuje direktor agencije AMM All Market Media Hrvoje Vukušić: „Radio se vratio na površinu, u fokus oglašivača. Velike tektonske promjene pokazuju koliko je radio snažan kao medij. Sve ovo prihvaćamo kao promjenu na tržištu i tako funkcioniramo. Klijenti percipiraju da je radio jači nego ikada i njegov utjecaj raste. Rubne situacije nam trebaju da pokažu koliko je radio jak. Promijenio se kontekst tržišta, klijenti ne planiraju daleko unaprijed, već od danas do najdulje 15 dana. Slotovi su se skratili, nema dugoročnih kampanja. Radio je brz medij i može isporučiti kampanju za dan, dva. Ne treba mu dugo planiranje." U usporedbi s drugim medijima, radio se, upravo zbog svoje brzine, vrlo brzo prilagodio promjenama na tržištu. Trenutni poslovni modeli su se modificirali, s naglaskom na prilagodbu i fleksibilnost. Uvedeni su hibridni modeli oglašavanja i kampanja, odnosno spoj dosadašnjih načina oglašavanja prilagođenih publici i trenutnoj COVID situaciji. 
Uloženi su i dodatni napori u promociju prednosti oglašavanja na radijskom mediju kroz brojne blogove, tekstove i sadržaje, kako na radiju tako i kroz druge medije i platforme. Radijske postaje bile su od početka pandemije vrlo aktivne na online platformama i društvenim mrežama u promocijama prednosti oglašavanja na radijskom tržištu. Tako su privukle nove klijente koji su prepoznali brzu prilagodbu i reakciju kao najveće prednosti radijskog medija. Ovakav način rada doveo je do češće upotrebe tehnologija i znanja te je proširio modele poslovanja s naglaskom na kreativnost i brzu reakciju. Radijski nakladnici pridobili su nove klijente, one koji prije koronakrize nisu ni razmišljali o oglašavanju na radiju. U novonastalim okolnostima, a zbog brze prilagodbe i jednako brze isporuke reklama i kampanja, novi su se klijenti odlučili na oglašavanje na radiju. Kako kažu ispitanici, „gubici u prihodima su nezamjenjivi, no sklopili smo suradnju s novim klijentima i uveli smo nove poslovne modele“. Radijski medij prilagodio je trenutne poslovne modele situaciji na tržištu te je kreirao hibridne modele oglašavanja i okrenuo se komunikaciji putem društvenih mreža, kaže direktor radijske postaje Antena Zagreb Hrvoje Barišić: „Trenutno je na radijskom tržištu dostupna kombinacija kampanja, reklama, promocija i drugih oblika marketinških aktivnosti, ovisno o potrebama klijenata i publike, nešto poput tailor-made oglašavanja, odnosno oglašavanja na zahtjev. Radijske postaje usredotočile su se na nove životne navike publike i stvorile nove modele oglašavanja koji su prilagođeni njihovim potrebama.“

Promjena okolnosti i drugačija priprema i produkcija programa dovele su do nekih dodanih vrijednosti, poput nove publike na društvenim mrežama te komunikacije sa slušateljima putem novih društvenih mreža, primjećuje direktor radijske postaje Enter Zagreb Dario Antunović: „Primjerice, kako bismo privukli neke od klijenata pokazali smo fleksibilnost u inače standardiziranoj programskoj shemi i oglasnim porukama, što se u nekoliko navrata pokazalo kao dobar potez. Na vrijeme smo prepoznali i potencijal TikToka, društvene mreže koja je svoj razvitak doživjela upravo u vremenu pandemije, što je klijentima također interesantno. Drugačijim pristupom sadržaju i određenim radijskim promocijama uspješno smo za oglašavanje pridobili određene klijente koji se inače ne bi nužno oglašavali na našem mediju, što smatramo značajnim uspjehom.“

Ispitanici iznimno korisnima i vrijednima smatraju mjere potpora državnih institucija i agencija, poput potpora za očuvanje radnih mjesta, COVID kredite te brzog donošenja odluke o relaksacijama određenih programskih zakonskih obveza. 


\subsection{Strukturirani intervju s čelnicima institucija/organizacija nadležnima za}

\section{radijsko tržište}

Strukturirani intervju proveden je i s čelnicima institucija, organizacija i agencija nadležnima za poslovanje radijskog tržišta u Hrvatskoj. Intervju je proveden elektronskim putem u veljači/ožujku 2021. godine, a pristupili su mu sljedeći ispitanici: ravnatelj Agencije za elektroničke medije i predsjednik Vijeća za elektroničke medije Josip Popovac; glavni direktor Hrvatske udruge poslodavaca Damir Zorić; ravnatelj HAKOM-a (Hrvatske regulatorne agencije za mrežne djelatnosti) Miran Gosta; član Uprave i direktor OIV-a (Odašiljača i veza) Mate Botica te glavni direktor HDS - ZAMP-a Nenad Marčec. Ispitanicima je postavljeno sljedećih pet pitanja:

1. Na koji je način pandemija virusa COVID-19 utjecala na kulturne i kreativne industrije u Hrvatskoj te kako je, prema Vama dostupnim informacijama, promijenila hrvatsko radijsko tržište?

2. Kojim ste aktivnostima i/ili mjerama potpora radijskim nakladnicima reagirali na pandemiju virusa COVID-19, odnosno na posljedice koje su utjecale na poslovanje radijskih nakladnika u Hrvatskoj?

3. Planirate li uvoditi nove aktivnosti ili mjere potpora radijskim nakladnicima u budućnosti kao mjere pomoći u poslovanju pri promijenjenim okolnostima na tržištu?

4. Kako će, prema Vašem mišljenju, nove okolnosti na tržištu utjecati na poslovanje radijskih nakladnika u budućnosti i uopće na radijsko tržište u Hrvatskoj?

5. Kako će, prema Vašem mišljenju, nove okolnosti na tržištu utjecati općenito na kreativne i kulturne industrije u post-pandemijskom svijetu?

Iz odgovora čelnika institucija, organizacija i agencija koje su, svaka u svom segmentu, nadležne za poslovanje radijskih nakladnika, vidljivo jest kako u tijeku pandemijskog razdoblja niti jedna radijska postaja nije zatražila prekid koncesijskog ugovora, dok nije sigurno da će se tako nastaviti i ubuduće. Ispitanici poručuju kako su kulturne i kreativne industrije najviše bile pogođene lockdownom. Ravnatelj Agencije za elektroničke medije i predsjednik Vijeća za elektroničke medije Josip Popovac kaže kako je koronakriza na ovaj segment gospodarske djelatnosti djelovala paralizirajuće: „Kulturne i kreativne industrije 
bile su možda i najveće žrtve zatvaranja gospodarstva i društvenih aktivnosti. Pretrpjele su materijalne, ali i stvaralačke gubitke koje će biti teško nadoknaditi.“ Kada govorimo o radijskom tržištu, najugroženiji su lokalni radijski nakladnici, kaže ravnatelj HAKOM-a Miran Gosta: „U ovom trenutku teško je procijeniti dugoročni utjecaj novih okolnosti na poslovanje radijskih nakladnika, no realno je za pretpostaviti kako su upravo najmanji nakladnici najugroženiji u uvjetima postojeće krize i kako će njihov opstanak na tržištu uvelike ovisiti o dinamici oporavka gospodarskih aktivnosti.“

Ono što je svakako najviše obilježilo pandemijsko razdoblje na radijskom tržištu jest otkazivanje marketinških aktivnosti, kampanja i promocija, dok su aktivnosti na online platformama u porastu, poručuje član Uprave i direktor OIV-a Mate Botica: „Fokus svih u značajnoj mjeri još uvijek jest na krizi, a promatrajući navedenu problematiku iz pozicije naše kompanije smatram kako su radijski nakladnici time izrazito pogođeni kroz umanjenje profita, odnosno otkazivanje marketinških, promidžbenih i drugih oblika prihoda. Naravno, dio kreativne industrije koji se bazira na online pristupu doživio je uzlet što će zasigurno u vremenu nakon izlaska iz krize donijeti i određene benefite kao i drugačiju percepciju umjetnosti u određenoj mjeri.“

U 2020. godini izdano je više privremenih licenci za upotrebu FM frekvencija za privremene događaje poput drive-in koncerata, drive-in kina te kulturnih i umjetničkih događaja i projekata. Ispitanici naglašavaju kako radijski nakladnici od početka pandemije mogu računati na njihovu, ali i snažnu potporu Vlade i fondova Europske unije u poslovanju, poput obročnog plaćanja dospjelih obveza, ukidanja naplata putem ovrha, raznih popusta na usluge, zatim relaksacija uvjeta plaćanja, potpora u očuvanju radnih mjesta te korištenja COVID-19 kreditnih linija. Također je relaksirano provođenje poslovnih aktivnosti i papirologije u smislu provođenja takvih aktivnosti online putem, poput ishođenja dozvola i razne poslovne dokumentacije, što, osim poštivanja epidemioloških mjera, ubrzava te aktivnosti i reducira troškove. Brzom reakcijom Vijeća za elektroničke medije relaksirane su i programske zakonske te koncesijske obaveze radijskih nakladnika, a sredstva iz Fonda za poticanje pluralizma i raznovrsnosti elektroničkih medija preusmjerena su prema onim nakladnicima kojima je trebala hitna financijska pomoć. Svi se ispitanici slažu u tome da će i u budućem razdoblju pomagati radijskim nakladnicima u skladu sa svojim mogućnostima, ali i njihovim potrebama, pružajući potporu poslovanju radijskih nakladnika te lobiranjem 
za relaksaciju njihovih zakonskih obveza. „Hrvatska udruga poslodavca će i dalje kroz HUP-Koordinaciju komercijalnih radijskih postaja, lobirati i raditi na svim aktivnostima koje za cilj imaju razvoj radio industrije kao gospodarske grane, posebice svojim aktivnim sudjelovanjem, u svojstvu socijalnog partnera, u procesu donošenja i izmjene relevantnih zakonskih i podzakonskih akata iz područja djelovanja radija, zatim ćemo raditi na daljnjem razvoju standarda u djelovanju komercijalnih radija te zaštiti komercijalnih uvjeta poslovanja radija“, poručuje glavni direktor HUP-a Damir Zorić.

Ispitanici predviđaju kako će se u budućnosti poslovanje radijskih nakladnika i suradnja s institucijama i agencijama provoditi kroz model kombinacije između „starog“ $i$ „novog“. „Sljedećih nekoliko godina kulturne i kreativne industrije trebat će snažnu pomoć od strane države i europskih fondova, kao i razne poticaje na ulaganja od strane privatnih poduzetnika i institucija. Nažalost, neki će pojedinci ili poslovni subjekti prestati s radom, ili to već jesu, no nove digitalne forme komunikacije i konzumacije kulturnih sadržaja na koje se publika ipak privikla tijekom korona krize otvorit će vrata i novim poduzetničkim idejama, formatima i modelima u svim kulturnim i kreativnim industrijama. Kreativci su prvi koji će se u tome dobro snaći“, mišljenja je glavni direktor HDS - ZAMP-a Nenad Marčec.

\subsection{Strukturirani intervju s čelnicima AER-a - Udruženja europskih radija}

Strukturirani intervju proveden je i s čelnicima AER-a - Udruženja europskih radija koje obuhvaća više od 5000 članica, radijskih postaja u zemljama Europske unije i Švicarske, uz Australiju kao dodatnog člana. Intervju je proveden elektronskim putem u veljači/ožujku 2021. godine, a pristupili su mu: predsjednik AER-a Stefan Möller (Danska), glavni tajnik AER-a Matt Payton (Ujedinjeno Kraljevstvo) te član Izvršnog odbora AER-a Luka Đurić (Hrvatska). Ispitanicima je postavljeno pet pitanja:

1. Kako je pandemija virusa COVID-19 utjecala na europsko radijsko tržište? Do kojih je konkretnih promjena dovela u upravljanju medijima?

2. Jesu li članice AER-a u ovim promijenjenim okolnostima stvorile neke nove modele poslovanja kako bi unaprijedile poslovne procese? 
3. Koje su od promjena članice AER-a zadržale u poslovanju, a za koje procjenjujete da će se zadržati u post-pandemijskom svijetu?

4. Surađivali ste blisko s europskim institucijama kako bi se donijele mjere potpora radijskim nakladnicima na razini Europske unije. Koje su mjere uvedene i gdje ima još prostora za napredak?

5. Kako procjenjujete da će radijsko tržište izgledati u post-pandemijskom svijetu?

Ispitanici potvrđuju kako prosječan pad radijskog tržišta u Europi iznosi između 10 - 20\%, dok je u nekim zemljama taj pad i veći. Marketinški budžeti te investicije u oglašavanju značajno su reducirani. Najjače je pogođeno tržište lokalnih radijskih nakladnika budući da su njihovi oglašivači većinom male lokalne tvrtke koje su najjače pogođene koronakrizom. Tržište lokalnih radijskih medija možda se nikada neće vratiti na razdoblje prije pandemije budući da sve više oglašivača u Europskoj uniji prelazi na digitalne medije, pojašnjava glavni tajnik AER-a Matt Payton: „, Radijsko tržište će se vrlo vjerojatno oporaviti paralelno sa širom gospodarskom slikom tijekom 2022. godine. Ipak postoji rizik da se prihodi od lokalnih oglašivača neće nikada vratit na razinu na kojoj su bili prije krize.“

Financijske pomoći Vlada zemalja članica AER-a razlikuju se od države do države, od primjerice potpora medijskim nakladnicima u Danskoj, zatim raznih potpora za financiranje specifičnih troškova poput odašiljanja u Ujedinjenom Kraljevstvu te potpora za pokrivanje troškova zaposlenika u Ujedinjenom Kraljevstvu i Francuskoj. Vlade europskih zemalja većinom su kroz potpore podupirale informativne medije, dok je radio percipiran kao medij zabave, stoga je AER iskoristio svoj glavni alat - lobiranje, te se u europskim institucijama zalagao za jednak tretman radijskih nakladnika, poručuje predsjednik AER-a Stefan Möller: „Vrlo je važno da je radijski medij tretiran jednako kada govorimo o državnim potporama. Informativni i drugi sadržaji na komercijalnim radijskim postajama jednako su važni kao i sadržaji na javnim medijima." Predstavnike europskih institucija upoznali su s podacima nacionalnih tržišta kako bi stekli bolji uvid i razumijevanje situacija u pojedinim zemljama. Kao rezultat lobiranja AER-a, europske institucije su radijske nakladnike uključile u dodjelu potpora kulturnom i kreativnom sektoru kroz 2,8 milijardi vrijedan budžet za Kreativnu Europu. Europska komisija i Europski parlament složili su se kako će povećati sredstva potpora kroz Fondove za obnovu. Pojam radijskog medija također je uključen u zakonodavne 
inicijative te će radijski nakladnici nastaviti dobivati potpore iz Europske unije, poručuje član Izvršnog odbora AER-a Luka Đurić: „Rekao bih da je Europa prilično dobro odgovorila na izazove koji su stavljeni pred cijelu medijsku industriju, pa tako i radio. S jedne strane mediji su bili ključni faktor informiranja građana o novonastaloj situaciji, a s druge strane komercijalnim medijima su, pogotovo u početku pandemije, značajno pali prihodi. Bio je izazov zadržati zaposlenike i očuvati poslovanje te istovremeno pravodobno, provjereno i objektivno izvještavati javnost. Programi financijske i druge pomoći iznimno su pridonijeli lakšem funkcioniranju radija kao i poslovnoj stabilnosti, što je opet preduvjet opstojnosti.“

\subsection{Utjecaj pandemije na radijska tržišta zemalja regije}

Kako bi usporedili posljedice utjecaja pandemije na hrvatskom radijskom tržištu i onome zemalja regije, proveden je strukturirani intervju s radijskim liderima iz Slovenije, Bosne i Hercegovine, Srbije i Makedonije. Strukturirani intervju proveden je elektronskim putem u veljači/ožujku 2021. godine, a pristupili su mu: kreativni direktor i voditelj produkcije Infonet medie Nejc Tisu, generalni direktor RSG Medie Adnan Osmanagić, konzultant BMC - Brand Media Consultinga Tomislav Jakobović te generalni direktor makedonskog City radija Gjorgji Savev. Ispitanici su odgovorili na sljedećih pet pitanja:

1. Kako je pandemija virusa COVID-19 utjecala na radijsko tržište u Vašoj zemlji? Što se promijenilo u upravljanju medijima, konkretno u upravljanju radijskim nakladnicima?

2. Na koji je način pandemija virusa COVID-19 utjecala na poslovanje Vašeg medija? Kako ste se prilagodili promjenama u npr. financijskom, tehnološkom i kadrovskom smislu, ali i drugim segmentima poslovanja?

3. Jeste li u promijenjenim okolnostima na tržištu stvorili nove modele poslovanja kako bi unaprijedili poslovne procese i, ako jeste, koji su to novi poslovni modeli?

4. Kako procjenjujete da će se ove promjene odraziti na poslovanje radijskih nakladnika u post-pandemijskom svijetu? Koje od promjena ste zadržali u poslovanju i koje ćete zadržati nakon pandemije virusa COVID-19? 
5. S kolikim padom prihoda u poslovanju su se susreli radijski nakladnici u Vašoj zemlji? Imate li procjene brojki u poslovanju za prvi kvartal 2021. godine? Je li došlo do otpuštanja zaposlenika u radijskoj industriji u Vašoj zemlji i, ako jest, u kojoj mjeri?

U zemljama regija situacija varira. U Sloveniji su tijekom koronakrize mediji učvrstili svoju poziciju, a radijski nakladnici bilježe porast slušanosti budući da je radio percipiran kao ključni medij za informiranje i zabavu, najjednostavniji i najdostupniji, poručuje kreativni direktor i voditelj produkcije Infonet medie Nejc Tisu: „Radio je preživio više od stotinu godina, a preživjet će i pandemiju. Mediji, pa i radio, su po pitanju pandemije dobili na važnosti u vrijeme svake velike krize. Radio se uvijek prikazivao kao medij koji se lako prilagođava kriznim situacijama." Koronakriza je očvrsnula suradnju među zaposlenicima u smislu timskog rada i zajedništva te povezivanja. Najgora situacija s pandemijom u Sloveniji dogodila se tek početkom 2021. godine jer je tada pandemija u toj zemlji bila na vrhuncu. Brojni oglašivači, njih čak $90 \%$, otkazali su unaprijed naručene kampanje. Radijski nakladnici bili su primorani okrenuti se custom made oglašavanju prilagođenom svakom klijentu te last-minute prodaji, a primijećena je i poboljšana suradnja između prodajnih i programskih odjela. Slovensko radijsko tržište primjećuje kako su klijenti sada pažljiviji i oprezniji. Pad prihoda u prvom kvartalu 2021. godine bio je između 30 - 40\%, a 20-30\% u 2020. godini. Procjenjuje se da je $20 \%$ zaposlenika radijskih nakladnika u Sloveniji izgubilo radna mjesta, a 20-30\% je i u 2021. godini na državnim potporama, čekajući da se tržište oporavi kako bi se mogli vratiti na posao. Plaće su isto smanjivane, a oporavak tržišta očekuje se do 2023. godine.

U Bosni i Hercegovini kriza je oslabila ionako nerazvijeno radijsko tržište. Klijenti su se u pandemiji povukli s tržišta, njih čak $80 \%$. Gubici u prihodima u 2020. godini dosežu 30\%, dok gubitak u prvom kvartalu 2021. godine iznosi 10-15\%. Radijski nakladnici reducirali su ukupne troškove, racionalizirali poslovanje, a većih otpuštanja nije bilo. Stvorili su se novi poslovni prioriteti - „financijska i programska stabilnost, očuvanje zdravlja i sigurnosti zaposlenika te smanjenje ukupnih troškova. Poslovni modeli pretvorili su se u online poslovanje, a suradnja između zaposlenika odvijala se distancirano i putem digitalnih platformi što će se dijelom zadržati i u budućnosti, budući da se na taj način ubrzavaju poslovni procesi te je poslovanje učinkovitije“, objašnjava generalni direktor RSG Medie Adnan Osmanagić. 
Procjena jest kako se neki radijski nakladnici u Srbiji nikada neće oporaviti od koronakrize čemu je pridonio i nedostatak strategije managementa u ovakvim iznimnim situacijama, poručuje konzultant BMC - Brand Media Consultinga Tomislav Jakobović: „Na samom početku bilo je važno očuvati komunikaciju s klijentima i donijeti hitne mjere kako bismo mi upravljali krizom, a ne kriza nama. No, dobar dio radijskih postaja, osim nekih manjih programskih izmjena, nije imao pravu strategiju upravljanja te su iste pretrpjele i najveće financijske gubitke, od kojih se neke radijske postaje nažalost nikad neće oporaviti." Pad u prihodima doseže do $40 \%$, a smanjenja u plaćama bila su pravilo, a ne iznimka. Primijećen je veći angažman publike i klijenata na digitalnim radijskim kanalima. Program se odvija putem distanciranih studija i online platformi, komunikacija sa slušateljima se povećava uz prijateljski pristup publici koja traži korisne informacije. Putem društvenih mreža ostvaruje se kontakt s publikom, koji služi i kao kanal za promociju. Primijećen je porast pratitelja i angažmana publike na digitalnim platformama.

U Makedoniji glavni su napori bili zadržati postojeće klijente i marketinške ugovore, no uz određene kompromise poput dampiranja cijena i posebnih uvjeta. Većih otpuštanja i rezanja plaća nije bilo, poručuje generalni direktor City radija Gjorgji Savev: „U prvom piku pandemije osjetila se razlika u zanimanju i mogućnostima novih klijenata za suradnjom. Srećom, većina dugogodišnjih partnera produljila je ugovore te smo se zajedno složili oko kompromisa vezano uz budžete, ovisno o mogućnostima klijenata. Tehnološki se nije investiralo mnogo, samo ono što je bilo neophodno." Promjene su se većim dijelom odnosile na programski sadržaj u produkciji i postprodukciji, program se odvija iz distanciranih studija uz nove formate u programu koji održavaju blisku vezu i komunikaciju sa slušateljem kroz glazbene emisije, kvizove te korisne informacije, privlačeći na taj način nove klijente. Stalna analiza tržišta ključna je za razumijevanje promjena koje se događaju.

\subsection{Pandemija koronavirusa - kriza ili prilika?}

Svim ispitanicima koji su pristupili ovom istraživanju postavljeno je i dodatno pitanje - Je li za Vas pandemija virusa COVID-19 kriza ili prilika? Najčešći odgovor bio je oboje, i kriza i prilika, ili kriza za sada, s optimističnim pogledom na budućnost. Kriza je stvorila neke nove modele poslovanja koji su se zadržali i nakon perioda lockdowna, no ispitanici se 
slažu kako su gubici u prihodima nenadoknadivi. Radijski medij je vrlo otporan i inventivan u pronalasku načina za razvijanje poslovanja. $S$ pozitivne strane, zbog sposobnosti radijskog medija na brzu prilagodbu radio je dobio novu publiku, većinom na digitalnim platformama i društvenim mrežama, ali i nove klijente i to radijskim nakladnicima daje razloga za optimizam. Primijećen je i dodatan angažman radijskih nakladnika u kreiranju programskog sadržaja, ali i marketinških aktivnosti, što donosi nove perspektive i prilike. Pandemija virusa COVID-19 prilika je da radijski medij bude još brži, bolji i kreativniji u pronalasku novih rješenja. Ispitanici također upozoravaju na važnost uloge kulturnih i kreativnih industrija, posebno medija, u oporavku tržišta od pandemije.

\section{Zaključak}

Kriza, kao rezultat pandemije virusa COVID-19, snažno je pogodila radijsko tržište u Hrvatskoj, uz gubitke u prihodima do $25 \%$, dok gubici na europskom radijskom tržištu dosežu i $30 \%$ pada profita radijskih postaja. Najugroženiji krizom uzrokovanom pandemijom virusa COVID-19 su lokalni radijski nakladnici, od kojih se neki možda nikada neće ni oporaviti od udara koronakrize. Radijsko tržište danas je potpuno drugačije i promijenilo se nepovratno. Stvorene su nove navike u oglašavanju bez dugoročnih planiranja kampanja. Pandemija je presložila odnose na radijskom tržištu, a radijski nakladnici morali su u kratkom vremenu promijeniti i prilagoditi poslovne procese novim okolnostima. Zahvaljujući prilagodljivosti i brzoj reakciji radijskog medija stvoreni su novi poslovni modeli na marketinškom tržištu, poput hibridnog oglašavanja, zatim oglašavanja na društvenim mrežama i digitalnim platformama, koji su se, kao primjeri dobre prakse i uspješnog prenošenja poruke, zadržali i nakon perioda lockdowna. Upravo zbog prilagodljivosti i brze reakcije radijski je medij uspio pridobiti i nove oglašivače koji su u periodu pandemije tražili brze i lako dostupne medije, a koji su u kratkom roku mogli prenijeti poruku od njenog izvora do krajnjih korisnika i konzumenata - publike. Državne institucije i regulatorne agencije su mjerama potpora, poput relaksacije financijskih i programskih zakonskih obveza, pomogle radijskim nakladnicima da očuvaju likvidnost i poslovne procese te je teško za pretpostaviti da bi se nakladnici uspjeli izboriti s koronakrizom da nije bilo takvih injekcija pomoći. 
Kulturne i kreativne industrije jedna su od važnijih grana gospodarstva, a mediji čine značajan dio ovog industrijskog sektora pa je razvoj medijske industrije iznimno važan za ukupni gospodarski rast zemlje. U budućem razdoblju jedino racionalizacijom poslovanja i redefiniranjem odnosa na poslovnom tržištu, uz sinergiju prodaje i programa, nakladnici na radijskom tržištu moći će dugoročno opstati. Tijekom pandemije, koja je promijenila okolnosti i odnose snaga na tržištu, važno je bilo stvorili nove modele poslovanja koji će se moći zadržati i nakon nje. Proaktivnost i progresivnost radijskih nakladnika u razdoblju nakon pandemije bit će ključni za postizanje krajnjeg cilja u oporavku radijskog tržišta, a to je konkurentnost te prilagodba radijske industrije tržištu novih medija i moderne tehnologije, uz ulaganje u digitalne ekstenzije radijskog programa i izjednačavanje uvjeta poslovanja na komercijalnom medijskom tržištu u Hrvatskoj s onima u Europskoj uniji.

\section{Literatura}

- Galloway, S., Dunlop S. (2007). A critique of definitions of the cultural and creative industries in public policy. International Journal of Cultural Policy, 13 (1), 17-31.

- Hesmondhalgh, D. J. (2008). Cultural and Creative Industries. U: The SAGE handbook of cultural analysis (str. 553-569). Sage Publications Ltd.

- Horizont.net (2021). Trust in media. Dostupno na: https://www.horizont.net/news/media/33/Trust-in-Media-Studie-derEBU--323478.pdf, 15. ožujka 2021.

- Hup.hr (2015). HUP Koordinacija kulturnih i kreativnih industrija. Dostupno na: https://www.hup.hr/kulturne-i-kreativneindustrije-vrijedne-vise-od-15-milijardi-kuna-ocekuju-rast-i-u-2016.aspx, 1. ožujka 2021.

- Hup.hr (n.p.). Mapiranje kulturnih i kreativnih industrija u Republici Hrvatskoj. Dostupno na: https://www.hup.hr/EasyEdit/ UserFiles/IASMINKA/Mapiranje\%20kreativnih\%20i\%20kulturnih\%20industrija\%20u\%20Republici\%20Hrvatskoj.pdf, 1. ožujka 2021.

- Larsson, L. (2009). Nordicom Review. PR and the Media A Collaborative Relationship? 30 (1): 131-147.

- Livingstone, S (1999). New media, new audiences? LSE Research Online. Dostupno na: http://eprints.lse.ac.uk/391/, 10. srpnja 2021.

- Pmu.e-mediji.hr (n.p.). Knjiga pružatelja medijskih usluga radija. Dostupno na: https://pmu.e-mediji.hr/Public/ PregledRadioNakladnici.aspx, 5. srpnja 2021.

- Rebuilding-europe.eu (2021). Rebuliding Europe EY Study. Dostupno na: https://www.rebuilding-europe.eu/, 18 . veljače 2021.

- Tomić, Z. (2017). Politički odnosi s javnošću. Synopsis.

- Zamp.hr (2021). Sažetak studije “Obnova Europe: kulturno i kreativno gospodarstvo prije i nakon COVID-19”. Dostupno na: https://www.zamp.hr/uploads/Obnova_Europe_Studija 2021 Gesac_Ev_KKI/Hrvatski_saetak_GESAC EY_studije_Obnova Europe.pdf, 18.veljače 2021.

- Zgrabljić Rotar, N. (2011.). Digitalno doba- masovni mediji i digitalna kultura. Sveučilište u Zadru. 


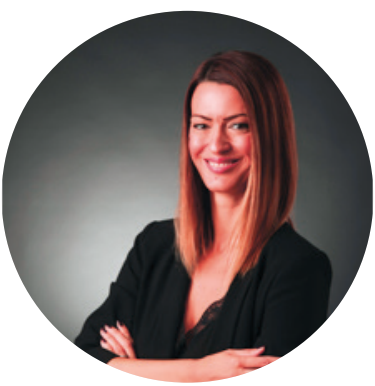

\section{Silvija Londero Šimleša}

Silvija Londero Šimleša je direktorica i glavna urednica Media servis globala, najveće hrvatske medijske agencije za proizvodnju radijskog informativnog programa. Predsjednica je udruge Hrvatski radijski forum i HUP - Koordinacije komercijalnih radio postaja. Članica je Uprave AGI - Amm Global Instituta, prvog hrvatskog instituta kreativne industrije. Predavač je na Sveučilištu VERN' i Edward Bernays University Collegeu. Završila je novinarski trening i edukaciju za medijske trenere $\mathrm{u}$ Reutersu $\mathrm{u}$ Londonu. Diplomirani je politolog, a završila je i poslijediplomski specijalistički studij Vanjska politika i diplomacija na Fakultetu političkih znanosti u Zagrebu. Doktorand je studija Komunikologije Doktorske škole Sveučilišta u Osijeku. 